\title{
The Features of Local Wisdom Within The Tradition of The Pondok Learning System
}

Mohd Zahirwan Halim Zainal Abidin, NoorAileen Ibrahim, Mohd Anuar Ramli, Muhammad Yusri Yusof @ Salleh, Paiz Bin Hassan, Abd.Munir Mohd Noh, Muhamad Imran Abd. Razak

To Link this Article: http://dx.doi.org/10.6007/IJARBSS/v12-i1/12108

DOI:10.6007/IJARBSS/v12-i1/12108

Received: 13 November 2021, Revised: 17 December 2021, Accepted: 27 December 2021

Published Online: 16 January 2022

In-Text Citation: (Abidin et al., 2022)

To Cite this Article: Abidin, M. Z. H. Z., Ibrahim, N., Ramli, M. A., Muhammad Yusri Yusof @ Salleh, P. B. H., Noh, A. M. M., \& Razak, M. I. A. (2022). The Features of Local Wisdom Within The Tradition of The Pondok Learning System. International Journal of Academic Research in Business and Social Sciences, 12(1), 956970.

\section{Copyright: (c) 2022 The Author(s)}

Published by Human Resource Management Academic Research Society (www.hrmars.com)

This article is published under the Creative Commons Attribution (CC BY 4.0) license. Anyone may reproduce, distribute, translate and create derivative works of this article (for both commercial and non0-commercial purposes), subject to full attribution to the original publication and authors. The full terms of this license may be seen at: http://creativecommons.org/licences/by/4.0/legalcode

Vol. 12, No. 1, 2022, Pg. $956-970$

Full Terms \& Conditions of access and use can be found at http://hrmars.com/index.php/pages/detail/publication-ethics 


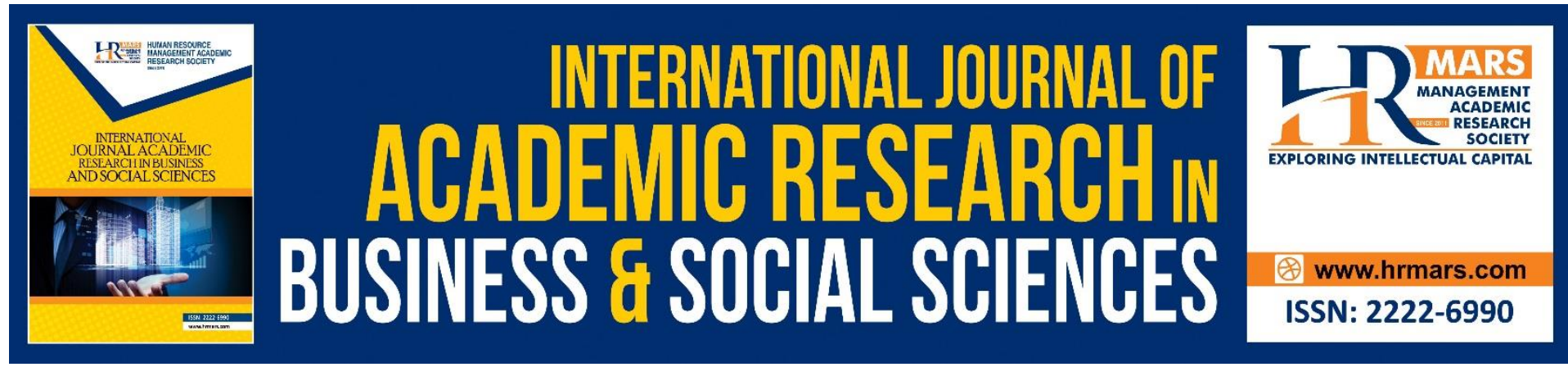

\title{
The Features of Local Wisdom Within The Tradition of The Pondok Learning System
}

\author{
Mohd Zahirwan Halim Zainal Abidin¹, NoorAileen Ibrahim², \\ Mohd Anuar Ramli³, Muhammad Yusri Yusof @ Salleh1, Paiz \\ Bin Hassan', Abd.Munir Mohd Noh¹, Muhamad Imran Abd. \\ Razak $^{1}$ \\ ${ }^{1}$ Academy of Contemporary Islamic Studies Universiti Teknologi MARA Perak Branch, \\ Seri Iskandar, 32610, Bandar Baru Seri Iskandar, Perak, Malaysia, ${ }^{2}$ Academy of Language \\ Studies Universiti Teknologi MARA Cawangan Perak, Seri Iskandar, 32610, Bandar Baru Seri \\ Iskandar, Perak, Malaysia, ${ }^{3}$ Department Fiqh and Usul Fiqh, Academy of Islamic Studies, \\ University of Malaya, 50603, Kuala Lumpur, Malaysia \\ Email:mohdz560@perak.uitm.edu.my
}

\section{Abstract}

Education plays a pivotal role in the development of any civilization. Within the Malay Archipelago community, the development of the civilization particularly the culture of acquiring knowledge was mainly limited to the elite upper class and the royalty. However, with the advent of Islam that focus on fairness and equality, knowledge was no longer limited to the upper echelon but also included everyone in the existing community without taking into account race or creed. In other words, the Islamic scholars established the pondok learning system to serve as a center of learning open to anyone interested in acquiring knowledge. This learning center focused on the halaqah system which is based on the syllabus of the yellow book (turath). It was considered an innovation within the local learning system. In light of that, this particular study will discuss the features of the local wisdom in the pondok institution system. In this study, the qualitative method is employed which includes library research to obtain the necessary data. Then, the data were analyzed through content analysis to formulate the findings. The research findings have shown that features of local wisdom within the tradition of the pondok learning system serves as a pioneer in the democratization of the religious education system whereby providing the earliest model of a learning institution which provides education for free to the community regardless of status. In addition, the existence of the pondok institution serves as an establishment which further strengthens the akidah of the Ahli Sunnah wal Jamaah and the Syafie sect within the Malay Archipelago. Hence, the pondok institution continued to thrive as a center for Islamic education which preserves elements of the turath study and continues to be relevant despite the change of times within the education system. The established features of local wisdom of the pondok institutions have greatly contributed to the countless charismatic religious scholars being produced, the vast intellectual development, numerous da'wah activities or 
propagation of Islam and the dissemination of Islamic religious knowledge among the Muslim community.

Keywords: Inclusive Education, Gender Equality, Free Education, Lifelong Education, Ahli Sunnah Wal Jamaah, Syafie Sect.

\section{Introduction}

The Malay Archipelago has its own uniqueness due to the diversity of its community in terms of race, tradition, culture as well as language. Besides being rich in precious minerals, this archipelago is also well-known for its intellectual community which is a reflection of the unique local lifestyle and mindset that is different from other Muslim communities (Rahim, 2013). The Malay community also possess a legacy of ancient treasures encompassing a legacy of cultural treasures that are tangible and intangible treasures. Both types of legacies are integral in building an intellectual community among the Malay community especially in the archipelago. Examples of tangible or physical cultural legacy includes artwork carvings, culinary delicacies and carpentry while intangible or non-physical cultural legacy includes knowledge and school of thought (Ramli, 2016).

The education system of the Malay community prior to the advent of Islam to the archipelago was informal and mainly focused on character-building, socialization skills, lifestyle, cultivating a sense of accountability as well as developing skills such as speaking skills rather on writing skills. The primary socialization process that had been cultivated through the family institution encompassed abilities or skills, character-building and familiarization with the local community. This particular process requires them to undergo numerous stages until they have reached a certain age where they will be able to further their studies in a specific field of knowledge (Ramli,2016).

The Islamization of the Malay community in the archipelago has led to various changes and improvements in terms of cultural, lifestyle and also level of knowledge of the local people. The change in terms of knowledge had occurred gradually especially as the dissemination of Islamic religious knowledge continued to increase and spread widely (Sulaiman, 2013). Furthermore, the Muslim Malay community in the archipelago had mainly focused on Islamic religious knowledge. Islam had also successfully introduced a culture based on acquiring knowledge and the cultivation of rational thought which rejects the superstitious and mythical beliefs which were widespread at the time. Islam is a comprehensive and pure religión which encompasses various religious principles leading to a better life as well as further strengthening the character of the Malay community ( Munawar, 2012). The Malay Civilization was further strengthened with the advent of Islam which included a corpus of Islamic religious knowledge such as fekah, tawhid and tasawwuf. Furthermore, the establishment of Islamic learning institutions which include surau and pondok led to the development of Islamic knowledge among the Malay community. The local religious scholars also served as catalyst that led to the development and dissemination of Islamic knowledge because they were the ones responsible in introducing and integrating a democratic learning system which is not only free for everyone but also inclusive without imposing any age restrictions.

\section{Literature Review}

From an anthropological perspective, the wisdom of the local scholars was mainly based on their firm religious beliefs, intelligence and traditions that helped shaped the behavior of various generations through the socialization process passed down to each 
generation through the years. The wisdom exhibited by the local scholars was also considered and accepted as values of the community as well as being regarded as the guidelines or standard of behavior and norms within that community. The wisdom of the local scholars also can be defined as the old traditions or norms of the local community particularly in terms of wisdom, knowledge and the teachings of the community passed down through the generations. The wisdom of the local community also includes the cumulative knowledge and beliefs passed to countless generations through cultural transmissión which relate to the relationship between mankind and the environment (Ramli \& Bakar, 2015).

Flavier (1995) has defined local wisdom as a type of knowledge unique to a specific community that has been shaped by the norms and culture of the said community. Eventually, this unique and fundamental knowledge has become the standard guidelines for the local community in making decisions in relation to their agricultural activities, health maintenance, food preparation, education, environmental and resource management (Warren, 1992). The local wisdom is also greatly influenced by the conditions and internal creativity as a result of interaction with the environment. Examples of local wisdom include local folklore, songs, proverbs, cultural values, beliefs, rituals, customary law, language and agricultural practices (Kumalah, 2015). According to Hiwasaki (2004) local wisdom refers to the comprehension, skills, practical and philosophy developed in relation to the environment. Some scholars defined local wisdom as the ability to master the local wisdom deeply as well as having a deep understanding of the philosophy behind the knowledge and wisdom. Affandi (2013) states:

\begin{abstract}
"Western scholars often refer to local wisdom as local genius. The word "wisdom"means deep understanding or intelligence based on contemplation and genuine reflection. The word "wisdom" often signifies the type of intelligence that reaches maqam al-Arifin. One of the qualities of a wise individual is someone who acquires information from the correct source or the information must be free from any doubts. It is imperative that the acquired information be true because if it is found to be untrue it could lead to the downfall of someone. This will adversely affect his reputation as well as cause havoc to his mindset."
\end{abstract}

Clearly, local wisdom is the network of information, clues, knowledge passed through the generations as a strategy which symbolizes the uniqueness of a particular race. Local wisdom is a result of the response of the Malay community with the surrounding environment as a way to survive which have a tremendous impact on the community.

The arrival of Islam has brought a tremendous change to the mentality of the Malay community in terms of academic and scientific matters while rejecting prior mythical and superstitious beliefs. Since Islam has been widely received by the community within the archipelago, the dissemination of Islamic knowledge and education have been developed by religious scholars and those propagating Islam. The entire community including kings, the aristocracy, and the locals were exposed to Islamic knowledge. This exposure has changed the perception of the Malay community towards religious values, culture and knowledge which is heavily influenced by Islamic values (Mohammad, 2008). With the numerous religious propagation activities and also religious education, Islam has successfully changed the perception of the Malay community in terms of religious beliefs, culture and knowledge (Sulaiman, 2013). Al-Attas (1999) stated: 
"We should see the arrival of Islam to the Malay-Indonesia archipelago as the beginning of a new era as this religion integrates rational thought and intellectual knowledge while establishing a social system based on upholding the rights of the individual, justice, and also excellent morals and character. Furthermore, Islam also establishes that intellect and discretion should go hand in hand while requiring justice to be upheld at all times. The Islamic teachings have spread far and wide throughout the archipelago. Therefore, it is apparent that Islam has brought forth tremendous change not only to the lives of royalty and the aristocrats but also to the lives of the general population."

With the advent of Islam, the education has been democratized whereby it is no longer monopolized and solely catered to the elite few but also to the masses. The religious scholars have established an inclusive learning system as an example of a democratized education system whereby it is a means of providing education to everyone from all walks of life and not only to the nobility. As a consequence, Islam is perceived as a religion that encourages others to gain valuable knowledge and a religion that will produce a community of learned individuals (Ramli \& Jamaluddin, 2018). The dissemination of knowledge proceeded to spread rapidly and extensively as more people developed a deep interest in acquiring a religious education (Yahya, 2001). There are several branches of religious knowledge that have a huge following which include Usuluddin, Fiqh, and Tasawwuf. The teaching of Islamic knowledge spread extensively throughout the archipelago such as Jawa, Banjar, Riau, Patani, Kelantan, Terengganu, and so forth (Mohammad, 2008).

Islam has greatly influenced the religious education system particularly with the establishment of the pondok learning institution which is also known as dayah, rangkang, zawiya, and pesantren. The growth of the pondok learning institution especially in Malaysia is actually the result of the Islamic education evolution which had initially began within the royal palace, homes of religious teachers, surau or mosque (Ishak, 1995; Azra, 2017).The pondok institution is an educational and teaching institution focusing on teaching Islamic teachings in an informal setting whereby the teacher will sit in the middle surrounded by his students (Thukiman, 2002) The term 'pondok' is derived from the Arabic word al-Funduq which means boarding house, hotel or hostel. However, this particular term has been incorporated within the Malay vocabulary and eventually evolved to have a specific meaning which relates to a certain pattern of traditional study focusing on religious education (Bakar, 1992). Pondok can also be defined as a learning center which has several smaller modes of accommodation to house the students within the confines of its compound. Pondok also refers to students' accommodation that are small houses or slightly bigger accommodation (Ishak, 1995). These pondok will normally be constructed near the homes of the religious scholars otherwise known as teacher, ustaz and kiyai who received their religious education from countries such as Makkah, Egypt, India or also from local pondok institutions which include Kelantan, Kedah or Patani. The location of these pondok as educational institutions are nearby madrasah, surau or mosque (Thukiman, 2002; Bakar, 1992). The religious scholars with the support of the local rulers and contributions from the surrounding community have successfully established new pondok institutions in various places. Eventually, the pondok learning institutions have been recognized as the earliest formal learning institution with a systematic management system in the archipelago (Ismail \& Othman, 2015). The pondok learning institution plays a monumental role in making an immense contribution in the 
dissemination of knowledge, upholding the traditional Islamic values, producing numerous potential religious scholars as well as creating a community that holds firmly to religious teachings and values (Ramli, 2016; Kompri, 2018).

\title{
Research Methodology
}

In this study, the qualitative method is employed which includes library research to obtain the necessary data. During the library research, various documents such as books, journals and proceedings were analyzed. Then, the data were analyzed through content analysis to formulate the findings. According to Lebar (2017), the analysis of documents and records are important to achieve a deeper understanding of the vast history and conditions related to the topic of study in question. The analyzed documents or records contain invaluable information about the life of the people involved in the study, the culture as well as the values of the community of this particular study.

\section{Discussion}

The Features of Local Wisdom within the Tradition of the Pondok Learning System. The pondok learning institution was established in Malaysia in the early 18th century. The earliest pondok established in Malaysia was pondok Tok Pulau Manis in Terengganu (Abdullah et al., 2019). Although it was claimed that Islamic education institution was first established in Pahang in the 16th century, there was no documented evidence to support this claim. According to Anuar (2016) the development of the pondok learning institution in Malaysia was linked to the influence of the pondok learning system located in Acheh, Sumatera and Patani. However, HAMKA (1981) claimed that the pondok institution began in Pasai as Pasai was involved in the efforts to spread the Islamic education and religious teachings.

The features of local wisdom within the teaching and learning system have been integrated into the pondok learning institution system. Evidently, these features have always been present within the traditional learning system and still in practice until the present day in the archipelago. Nevertheless, the religious scholars have taken steps which led to the democratization of the education system to ensure everyone, not just the elite few, will receive a good education particularly religious education. Furthermore, Diah (1989) defined democratization of education as:

\begin{abstract}
"Everyone regardless of creed or status rightfully deserves a sound education provided by religious scholars who will help the future generation to cultivate and possess excellent moral character which will guarantee the success of the society and country. In short, the democratization of education means that everyone will be provided with a good education regardless of his status and that no one will be discriminated against in terms of receiving a good education although he might not be rich or belong to a certain social class."
\end{abstract}

The democratization of education has been applied by the pondok learning institutions based on several aspects that are linked to the features of local wisdom. Rahimin Affandi (2010) stated that past religious scholars were thorough and have carefully planned prior to establishing the pondok institution. As a result, this particular institution has made numerous contributions to the field of knowledge. The education provided to the community was not radical whereby it did not outright reject the practice of the Malay community 
passed through the generations as long as the practice did not contradict the Islamic teachings. The Islamization process was conducted gradually through the education system so as not to cause confusion and discomfort to the surrounding community (Rahim, 2015).

The pondok education system also emphasized on the relationship between theory and practical which focused on instilling a love for knowledge or a culture of gaining knowledge among its learners. By doing this, the learners will reap benefits in terms of receiving the blessings from Allah SWT, behaving or acting based on religious knowledge and values, spreading knowledge to others, becoming independent, disciplined and possesing excellent character. The pondok learning institution has an open concept ('umumi) that provides opportunities to anyone regardless of age, gender, race, background, qualification and status. This approach is linked to the democratization of the education system that is based on priorities and the importance of knowledge to all Muslims as well as the right of every individual to receive an education particularly religious education (Rahim, 2015). The 'umumi system is an education system which provides education to anyone and not only to learners of the pondok institution. The students and the general public are allowed to decide which academic or religious classes they would like to attend based on the subject offered, the books used and time of the classes being held. However, generally the scholars will decide which book will be used in class based on their own level of expertise particularly religious subject.

The pondok learning institution is inclusive in terms of not imposing any age limit and is offered for free without any imposed fees. Consequently, this led to the democratization of knowledge (Ramli, 2016). Those interested in learning will be accepted without having to fulfill any set conditions. As a result, this had made it easier for the community to further their studies in religious education. Islam is about fairness and justice and the pondok learning institution is a reflection of this Islamic teaching which advocates equality and avoiding prejudice and discrimination. This pondok learning institution has become a recognized education institution as a result of this particular beliefs and values until the present day. Moreover, an Islamic education is a form of life-long education. Therefore, the pondok learning institution has held true to these values which does not impose any age limit and also marital status whereby those who are single or married are most welcome to become a student at the pondok institution (Bakar, 1992).

The pondok learning institution is free of charge. The religious scholars impart knowledge out of the sincerity of their hearts. These scholars also do not have a fixed income as most of their time are spent teaching and imparting knowledge to the community. However, the management of the pondok learning institution do provide for the scholars through the contributions of the community, zakat, donations and the help from the students of the pondok (Ramli \& Bakar, 2015). In addition to receiving religious knowledge, the students of the pondok are also taught certain skills in order to make a living in the future and help their religious scholars in their daily activities. Furthermore, there were also scholars who were successful entrepreneurs and indirectly had motivated their students to become successful in their chosen field as well. Clearly, the business endeavors were successful because the pondok institutions located in the rural area had produced countless individuals that generated income for the community. Moreover, this also led to many other pondok learning institutions being established while the teachers and students also successfully established close ties with the surrounding community (Rahim, 2015).

The students of the pondok institutions came from a diverse background and social status (Abdullah, 2011). The teaching and learning methods employed at the pondok 
institutions had instilled a sense of brotherhood, kinship and love regardless of social status, education level, economic status, race, and background (Rosmanah, 2013). These differences are of no importance as Islam advocates each mukmin or Muslim to establish a good relationship with others while focusing on acquiring religious knowledge. The participation of each students in the pondok institution such as the halaqah method is open to all and the education provided is free of charge. Hence, these factors created a conducive learning environment as the students are not judged or evaluated based on their background and social status.

In addition, the students at the pondok institution comprise of male and female students regardless of age. This is testament that the pondok learning institution advocates equality in education irrespective of gender or age and not catering to specific groups of society. This openness in accepting students regardless of age or gender has led to the rapid dissemination of knowledge. Moreover, senior citizens such as old women were allowed to stay at the accommodation within the compound of the pondok to enable them to attend religious classes easily and frequently. This open and just concept of the pondok institution not only culminated in establishing the pondok as a religious education institution but also as a center that provides service to the community particularly to those in need such as the elderly (Ramli \& Bakar, 2015).

The scholars leading the pondok learning institution possess autonomy in determining the system and syllabus without any restrictions. The pondok institution does not impose a specific syllabus, as the scholars are given free rein to decide which books to use or subjects to teach, and the syllabus is not determined by any other academic institution. Each pondok is managed and led by a Master Scholar and is it he who will determine the syllabus and books to be used based on his own expertise in a particular subject. Every pondok institution is different and has its own method of teaching as well as has the autonomy to use any book they prefer. This difference is mainly due to the capability of the Master Scholar, the students and the surrounding community (Ishak, 1987). As a result, each pondok institution is considered unique and special as the syllabus offered is based on the expertise of its scholars such as fekah, usuluddin or tasawwuf. The class schedule also depends on the initiative of the pondok management (Bakar, 1992). However, in Malaysia the pondok institutions do abide a certain standard whereby only certain books are used and certain subjects are offered to the students. In general, the subjects taught at these pondok are Nahu, Saraf, Fiqh, Usul Fiqh, Tafsir, Tauhid, al-Quran, Hadith serta Tasawwuf. These are the main subjects taught at most pondok institutions in the archipelago (Ishak, 1987). Among the books used in these pondok institutions include Hidayatul Mustafid (Tajwid), Munniyat al-Musalli, Matla' al-Badrain and Sullam al-Mubtadi (Fiqh), Matan al-Arbain, Riyadhu al-Salihin, Sahih al-Bukhari and Bulugh al-Maram (Hadis), Tafsir Nur al-Ihsan, Jalalain and al-Baidhawi (Tafsir), Faridatul Faraidh, Kifayatul 'Awwam, 'Aqidah al-Najin and Dur al-Thamin (Akidah) as well as Pelita Penuntut, Penawar Bagi Hati, Hidayah al-Salikin, Hikam and Minhaj al-'Abidin (Tasawwuf).

The sign of charismatic scholars that are highly knowledgeable and recognized as religious scholars can be seen when they are able to establish the pondok learning institution while increasing the number of students as time goes by. They also impart knowledge sincerely without expecting anything in return. The role and position of the scholar as an educator or teacher is also elevated as he is also considered as a spiritual guide who can instill noble values among his students as well as regarding all his students as his own children (Rahman, 2009). The religious scholars or teachers should also possess a high level of knowledge, good moral values and excellent character as well as a firm commitment 
toward imparting Islamic knowledge while being a good role model to his students. The teacher should also be optimistic, religious, ethical, possessing excellent morals, charismatic, resolute as well as appreciates the efforts shown by his students (Tamuri \& Ajuhary, 2010). In addition, the pondok scholars were well-respected and recognized as their level of knowledge is unrivalled as well as possessing a charismatic personality. Due to these excellent qualities possessed by the scholars, they have earned the respect of their students. Inadvertently, this led to the students becoming more disciplined and well-behaved as they have a deep respect for their scholars while the relationship between the scholars and students was also driven by mutual respect. A conducive environment based on solidarity was also heavily emphasized whether it was among the students of the pondok or between the students and the surrounding community (Ramli \& Bakar, 2015). These values created a lasting and positive bond among them which ultimately ensured that a conducive environment promoting mutual respect is maintained until today. According to Luqman Abdullah (2018) the standard or benchmark in ensuring high quality individuals are produced by the pondok institutions is based on the following aspects: the teaching method employed by the scholars, the attitude of students towards the scholars, the relationship between the scholars and their students as well as the respect shown to the scholars. Clearly, due to the fact that all these aspects are fulfilled, the pondok institutions are able to produce individuals of high moral caliber and experts in their chosen field who helped further spread Islamic religious knowledge to the world.

Besides that, there was no time limit and restrictions imposed whereby this enabled the students to further their knowledge and continued learning from the scholars as much as they could. The students of the pondok institution are encouraged to acquire as much knowledge as they require and this means they can stay at the pondok accommodation for as long as they wanted to (Ismail \& Othman, 2015). The students are not compelled to stay at one particular pondok and are in fact, they were free to move to another pondok institution if they feel that they have gained adequate knowledge at one particular pondok (Saadon, 2016). The system implemented at the pondok institution is flexible and not limited to any time constraint. Normally, studies would start early in the morning and end in the evening (Ramli, 2016). Generally, classes will begin after the completion of the fard' or obligatory prayer and end late at night, on a daily basis. In addition, the tutorial system is conducted by the senior student referred to as the Head of Mutala'ah and upon special request particularly by new students, he would conduct classes at the home of these students. The pondok scholars would entrust the Head of Mutala'ah to guide the young and new students in terms of gaining knowledge and also instilling a sense of discipline.

The Malay scholars had established a systematic Islamic education sysrem which had adapted to the local Malay community at the time. One of the ways of adapting is by adopting the halaqah learning method based on the learning system implemented in Masjidil Haram, Makkah. This particular method had been modified to integrate the Malay lifestyle such as providing modes of accommodation, the attire worn by the Malay community and so forth which had created a pondok learning system which was geared for the local community particularly in Malaysia (Rahim, 2015). The scholars were wise to incorporate the Malay culture as a sign of respect for the local community and avoided integrating the culture from the Middle East in general (Nasir, 2018). As a result, the Malay culture was preserved while only a few Islamic practices from the Middle East had been integrated. This was done to attract the Malay community to delve deeper into Islamic teachings while ensuring ease for them to apply religious knowledge in their daily lives. For instance, besides 
the traditional robe and turban the students are allowed to dress in their traditional Baju Melayu and sarong. According to the present Malay perspective, this type of attire has been the norm throughout the generations. Moreover, it has become the normal way of dressing for the students at the pondok institution until the present day. Although there are various modes of modern attire nowadays, the traditional attire is still worn by the Malay community today. Hence, it has become the unique identity of the scholars and students of the pondok institutions. It is akin to a standard uniform and is accepted by the pondok community.

Besides that, the halaqah system based on group learning was also incorporated at these pondok institutions. This means the students sit cross-legged on the floor in a semicircle facing their teacher or scholar as the latter explains the subject taught. In each halaqah, the students will also use a specific book or text chosen by that particular pondok institution (Hamid, 2010). The learning process is conducted via the talaqqi method particularly (tahqiq) which means learning at a deeper or extensive level. The students are required to fully comprehend what they are learning and will only go to the next lesson only after they have completely understood the lesson in question (Hayimasae, 2013). The students will make notes in the right and left column of the book or text they are learning and this is referrred to as dhabit. Dhabit is a specific term which means making notes (Bakar, 1992).

In the halaqah method, the talaqqi method is implemented in the learning process. Talaqqi means that the students will sit facing the scholar whether it is to listen to the Quranic verses being recited by the scholar or to directly listen to the teaching or explanation made by their scholar without any interruption. The scholar and students will sit cross-legged or sit on chairs or sometimes it is only the scholar who will be sitting on a chair while the students sit cross-legged facing their scholar and referring to their text or book (Rahim, 2015). In addition, the talaqqi method can also be conducted in larger groups and not just smaller ones. This teaching method will not only create a dependence on the scholar as the one imparting knowledge, but it will also create a sense of respect towards their scholar or teacher as they are the ones who are more knowledgeable (Jaafar \& Tamuri, 2012).

\section{Discussion}

The Impact of Local Wisdom within the Tradition of the Pondok Learning System Towards the Akidah and Fiqh of the Archipelago.

\section{Strengthening the Akidah of Ahli Sunnah wal Jamaah}

The beliefs and practice of the Malay community particularly in Malaysia is synonymous with the akidah of the Ahli Sunnah wal Jamaah from the Asya'irah sect. The main reason that the Malay community follows the Asya'irah sect is because the propagation of Islam in the Malay states at the time was centered on the Asya'irah religious stream ( Badhrulhisham, 2016). The Akidah or Oneness of God or the Tauhidic institute of traditional studies in the archipelago generally and particularly in Malaysia is centered upon the akidah of the Ahli Sunnah wal Jamaah pioneered by Imam Abu Hasan al-Asya'ari (Abdullah, 1998). This particular religious stream maintains and protects Islam which is based on the holy teachings contained in the Al-Quran and al-Hadith because at the time, there were many contradictory streams of akidah such as Muktazilah (Badhrulhisham, 2016). The pondok learning institution played a fundamental role in propagating the Islamic religion based on the akidah of the Ahli Sunnah wal Jamaah. This akidah has led to the establishment of a tolerant Muslim community and became the catalyst in upholding beliefs steeped in values that veered upon leading a moderate lifestyle while outright rejecting beliefs based on 
extremism (Dasuki, 2016 ; Tamam, 2015). Furthermore, this akidah has successfully united the Malay community based on the akidah of Asya'irah, fiqh of the Syafie sect as well as the Tasawwuf of Imam al-Ghazali (Ahmad, Rushdi \& Shakila, t.t.)

Most of the materials used in teaching and education are based on the works of the great scholars of the Ahli Sunnah wal Jamaah based on the akidah of Asya'irah as the Malay scholars adhered to that particular akidah. The religious scholars in the archipelago have written numerous texts in jawi with detailed explanations which emphasized on the characteristics and qualities of Allah swt, apostles and prophets, jins, angels, natural phenomenon and the creation of mankind based on the akidah of Asya'irah (Kamarudin, 2013). The pondok learning institution and pesantren or Quranic schools apparently played an important role in spreading the akidah of Asya'irah throughout the archipelago while maintaining the tradition of using as reference the various jawi texts of the Malay religious scholars of the Asya'irah akidah until the present day (tanwir.my 2018). These texts of akidah based on this particular manhaj have become the main syllabus of the studies at the pondok instititutions. Some of these texts include Dur al-Thamin, Aqidah al-'Awwam, Kifayatul 'Awwam, Jawhar al-Tauhid, Aqidah al-Najin, Faridatul Faraid dan 'Umdat al-Murid.

Therefore, generally the development and the deep belief in the akidah held by the Ahli Sunnah wal Jamaah had successfully spread through numerous medium such as propagation activities, written texts, teaching and education. All of these efforts have further led to the establishment of this particular akidah and elevated its status as the main belief firmly held by the Muslim community in the archipelago and specifically in Malaysia.

\section{The Continuation of the Practice Among the Syafie Sect}

Studies in the field of fiqh which orientated within the Syafie sect was most dominant in the archipelago and specifically in Malaysia. Studies in the field of fiqh traditionally defends the conventional fiqh until the religious scholars began to write religious texts based on the beliefs held by the Syafie sect which eventually led to them being spread within the archipelago (Bruinessen, 2015). The religious scholars had also established the pondok learning institution in such a unique and systematic manner within the archipelago (Azra, 2004). The sect practice is an Islamic tradition which is a paradigm of thought of the Muslim community among certain fuqaha scholars regarding the Syariah method. The belief held by the Malay community in the Syafie sect has been passed down through the generations and implemented in their acts of worship. This firm belief in the Syafie sect still holds true until the present day and is still relevant because it refers to the expertise and knowledge of the religious scholars in matters related to Islamic teachings. In this way, it will prevent further confusion in the future regarding religious matters particularly when some Muslims not wellinformed in Islam might misinterpret the religion unintentionally. Clearly, the Syafie sect will provide clear guidelines and prevent possible confusion in the future. In addition, the needs of adhering to the Syafie sect is also of great importance in ensuring stability in terms of the socio-political situation of the Muslims which will enable the smooth implementation of Islamic law. The practice of the Syafie sect is still in place until today because it is suitable with the lifestyle of the Malay community. The culture of being open and friendly as implemented by the religious scholars of the Syafie sect had received strong support from the political administrators which enabled Islam to spread even further in the archipelago. Furthermore, the harmonious nature of the Syafie sect which combines the sufi and figh paradigm (Neo-Sufism) had indirectly led to an apparent and tremendous positive effect in the Islamization process of the Malay community (Rahim, 2013). Besides that, the nature of 
the Malay people who are gentle, moderate and filled with wasatiyyah are compatible with Islamic teachings. Another factor is that the Syafie sect is an integration between 2 aspects which include intellect and revelation which made it even easier for it to be accepted. Hence, the nature of the Malay community mentioned above and the integration of these 2 aspects are the factors that led to the acceptance of the Syafie sect by the Malay community (Ramli, 2016).

There were many religious scholars within the Malay community that had contributed in the aspect of local wisdom regarding the field of fiqh and among them include the following: Syeikh Muhammad Arsyad al-Banjari, Syeikh Abdul Samad al-Palembani and Syeikh Daud Abdullah al-Fatani. The religious texts produced by these scholars had left a tremendous impact in the lives of the Malay community as the texts have become the reference within the region. The features of local wisdom in the field of knowledge had produced a Malay community with a firm belief in religion and the noble Islamic values (Ramli, 2010).

It is apparent that the pondok learning institution is an agent of change and play a significant role in spreading the Syafie sect to the Muslim community within the region (Usman, 2013). The fiqh syllabus being used by the religious scholars emphasized on the fatwa by Imam al-Syafie because the religious texts used are based on the Syafie sect (Mahaiyaddin, 2017). Through the pondok learning institutions, the main references in use until the present day are texts based on figh and translations from the Arabic to the Malay language by the Malay scholars of the past who adhered to the Syafie doctrine. Some texts in the field of fiqh that were translated from Arabic to Malay include Minhaj al-Talibin dan Fath al-Qarib. Generally, the studies in the field of figh conducted at the pondok learning institutions were based on the fiqh of the Syafie sect whereby all the texts used in teaching were by religious scholars of this particular sect. Moreover, some of the texts of fiqh based on the Syafie sect written by Malay religious scholars became the main syllabus at the pondok institution until the present day which include the following: Fath al-Mu'in, Sabil alMuhtadin, Matla' al-Badrain, Munniyat al-Musali dan I'anah al-Talibin

\section{Conclusion}

The pondok education system has successfully maintained the tradition of the turath studies which had been passed down through the generations. The integration of the features of local wisdom into the present education system of the pondok learning institution in the archipelago is a testament that it is indeed a legacy that had not been neglected. Furthermore, this legacy is aligned with the Islamic teachings when it spread widely in the archipelago. The advent of Islam has indeed led to the democratization of the education system in the archipelago and is a breath of fresh air in the development of education and Islamic teachings. The level of wisdom possessed by the religious scholars had led to the development and establishment of the pondok learning system which play several important roles and is not merely limited as a center of education but also as a center that unites the community in terms of religion, social and economy. Besides that, the pondok learning system promotes a fair and just system which does not discriminate any particular gender or impose any age limit. Moreover, the pondok institution also serves as a center for the elderly interested in religious studies besides producing numerous individuals with the potential of becoming religious scholars in the process. All of these factors are indeed the features of local wisdom in the Islamic education system. Clearly, this has led to a positive result in terms of 
developing a culture which promotes acquiring knowledge as well as developing a strong and harmonious Malay Muslim community.

\section{References}

Abdullah, A. R. (1998). Pemikiran Islam di Malaysia:Sejarah dan Aliran. Pulau Pinang: Universiti Sains Malaysia.

Abdullah, A. H., Sulaiman, A. Z., \& Hamzah, M. S. (2019). Sejarah Perkembangan Institusi Pengajian Pondok di Negeri Terengganu. Kuala Nerus : Penerbit UNISZA.

Abdullah, L. (2011), Latest Development of Traditional Islamic Education in Kelantan. (pp.291300), INTED 2011,7-9 March 2011, Valencia, Spain.

Ahmad, S., Rushdi, M., \& Fatah, R. A. A. (t.t.). Usaha Memartabatkan Akidah Ahli Sunnah Wal Jamaah Sebagai Pemangkin Kelangsungan Masyarakat Islam Madani di Malaysia. Fakulti Sains, Teknologi dan Pembangunan Insan, UTHM. Retrieved from eprints.uthm.edu.my/4761/

Al-Attas, S. M. N. (1999). Islam Dalam Sejarah dan Kebudayaan Melayu. Kuala Lumpur: ABIM

Ali, W. Z. K. W. (2013), al-Asya'irah Dalam Dunia Islam dan di Malaysia. Retrieved from https://www.researchgate.net/publication/257367955_AlAsya\%27ariyyah_dalam_Dun ia_Islam_dan_di_Malaysia_pdf.

Azra, A. (2004). Jaringan Ulama Timur Tengah dan Kepulauan Nusantara Abad XVII \& XVIII. Edisi revisi, Jakarta: Kencana.

Azra, A. (2017). Surau: Pendidikan Islam Dalam Transisi dan Modernisasi. Banten: PPIM.

Badhrulhisham, A. (2016). Ahli Sunnah Wal Jamaah Dan Pemakaiannya Di Malaysia: Isu Dan Cabaran. Jurnal 'Ulwan. Jilid 1. pp. 128-149.

Bakar, S. (1992). Perkembangan Islam Di Malaysia. Konsep Pembangunan Dan Kenegaraan Malaysia. Bangi: Universiti Kebangsaan Malaysia.

Bruinessen, M. V. (2015). Kitab Kuning, Pesantren dan Tarekat. Cetakan 2, Yogyakarta: Gading Publishing.

Diah, A. H. M. (1989). Islam dan Demokrasi Pendidikan. Kuala Lumpur: ABIM.

Dusuki, A. W. (2016). Pengajian Pondok Benteng Akidah. Sinar Harian $7^{\text {th }}$ September 2016. Retrieved from www.sinarharian.com.my

Hamid, A. F. A. (2010). Islamic Education in Malaysia. Singapore: S. Rajaratnam School of International Studies.

HAMKA. (1981). Dari Perbendaharaan Lama. Kuala Lumpur : Pustaka Antara.

Hayimasae, N. (2013). Intellectual Network of Patani and the Haramayn in Patrick Jory (ed.), Ghost of the Past in Southern Thailand. Singapore: NUS Press.

Hiwasaki, L., Luna, E., Syamsidik, S. R. (2014). Local And Indigenous Knowledge For Community Resilience: Hydro-Meteorological Disaster Risk Reduction And Climate Change Adaptation In Coastal And Small Island Communities. UNESCO, Jakarta.

Ishak, A. (1995), Pendidikan Islam dan Pengaruhnya di Malaysia. Kuala Lumpur : Dewan Bahasa dan Pustaka.

Ishak, M. S. A. (2000), The Malays In The Middle East, With A Bibliography Of Malay Printed Works Published In The Midde East. Kuala Lumpur : University of Malaya Press.

Ismail, A. M., Stapa, Z., Othman, M. Y., \& Yaacob, M. (2012), Islam Dalam Pendidikan dan Hubungannya Dengan Pembentukan Jati Diri Bangsa Melayu di Malaysia. Jurnal Hadhari Special Edition, pp. 37-50.

Ismail, S., \& Othman, Z. (2015), Pembangunan Pendidikan Islam Tradisional Dalam Komuniti ASEAN: Perbandingan Antara Malaysia, Indonesia dan Thailand (pp.1-15), Proceeding of 
2nd International Conference on Innovation and Sustainability ( ICOIS 2015), Duangtawan Hotel Chiang Mai Thailand on 12-13 November 2015.

Jaafar, N., \& Tamuri, A. H. (2012). Pedagogi Rasullullah SAW Dalam Pengajaran (pp.1-16). Proceeding of Persidangan Kebangsaan Pendidikan Islam 2012 on 3-6 July 2012 in Royale Bintang Hotel, Seremban, organized by IPG Kampus Pendidikan Islam Zon Tengah.

Jusoh, A. (1990), Pengenalan Tamadun Islam di Malaysia. Kuala Lumpur: Dewan Bahasa Dan Pustaka.

Kompri (2018). Manajemen \& Kepemimpinan Pondok Pesantren. Jakarta: Prenadamedia.

Kumalah, M. J., Saat, G., Mapjabil, J., Hussin, R., Afrizal, T., Talip, M. A. (2015), Kearifan Tempatan Dan Potensinya Sebagai Tarikan Pelancongan Berasaskan Komuniti: Kajian Kes Komuniti Bajau Ubian Di Pulau Mantanani, Sabah. GEOGRAFIA Journal of Society and Space, 11 (12), pp. 112-128.

Lebar, O. (2017). Penyelidikan Kualitatif Pengenalan Kepada Teori dan Metode. Tanjong Malim:Penerbit UPSI.

Mahaiyadin, M. H. (2017), Ini Mazhabku:Bagaimana Saya Beriltizam Dengan Mazhab. Selangor: Inspirasi Media.

Mohammad, A. (2008) Sumbangan Tamadun Islam Dalam Kehidupan Masyarakat Di Alam Melayu Hingga Abad Ke-17 M. Jurnal al-Tamaddun Bil.3 (1). pp. 68-84.

Nasir, B. M., Rahim, R. A. A., \& Ramli, N. M. (2018), Institusi Pondok Tradisional dan Pembangunan Intelektualisme Islam Masyarakat Melayu-Islam:Analisis Kritikal. Retrieved from https://www.academia.edu/23981087

Rahim, R. A. A., Noor, R. M., Yusoff, N., \& Dzulkifli, M. I. H. (2015). Institusi Pondok Tradisional Sebagai Model Kearifan Melayu-Islam: Antara Tradisi dan Harapan in Salasiah Che Lah, Norizan Esa (Ed.), Ilmu, Tradisi dan Kelestarian Dalam Kearifan Tempatan. Pulau Pinang: Universiti Sains Malaysia.

Rahim, R. A. A. (2010). Paradigma Tradisionalisme Dan Pentadbiran Undang-Undang Islam Dan Fatwa Di Negeri Kelantan: Satu Analisis Sejarah. Jurnal Malaysia Dari Segi Sejarah V. 38, pp. 25-44.

Rahim, R. A. A., Nor, R. M., Dahlal, N. H. M., \& Hamid, N. A. (2013), Islam dan Kearifan Tempatan di Alam Melayu: Analisis Kritikal. Jurnal JATI. Volume 18, pp.223-245.

Rahim, S. I. A. (2015), Pedagogi Talaqqi Dalam Pendidikan Islam di Pondok (pp.21-27), EProceeding Of The 3rd Global Summit On Education GSE 2015 (E-ISBN 978-967-0792-011), 9-10 March 2015, Kuala Lumpur, Malaysia.

Rahman, A. B. A. (2009). Pendidikan Islam Tradisional dan Relevensi Dengan Keperluan Semasa. Pendidikan Tinggi Islam Cabaran dan Prospek. Shah Alam: UPENA.

Ramli, M. I., \& Bakar, M. Z. A. (2015), Kearifan Tempatan Dalam Institusi Sekolah Pondok di Malaysia in Salasiah Che Lah, Norizan Esa (Ed.), IImu, Tradisi dan Kelestarian Dalam Kearifan Tempatan. Pulau Pinang: Universiti Sains Malaysia.

Ramli, M. A., \& Jamaluddin, M. A. (2018), Sumbangan Ulama Melayu Klasik Dalam Menjana Budaya Ilmu di Alam Melayu. Retrieved from https://www.researchgate.net/publication/255991975_Sumbangan_Ulama_Melayu_K lasik_Dalam_Menjana_Budaya_Ilmu_Di_Alam_Melayu

Ramli, M. A. (2010). Pemikiran Mesra Gender Dalam Karya Fiqh Ulama Klasik. Jurnal Syariah. Vol.18(2), pp.277-298. 
Ramli, M. A., Rosele, M. I., Jamaluddin, M. A., \& Sidik, M. A. (2016), Sumbangan Ulama Melayu Klasik Dalam Pembinaan Kearifan Tempatan di Alam Melayu. Jurnal Pengajian Melayu. Vol. 27 (1), pp.180-198.

Ramli, M. I., \& Bakar, M. Z. A. (2013), Kearifan Tempatan Dalam Institusi Sekolah Pondok: Kajian Kes di Malaysia (pp.1-12), Prosiding Persidangan Serantau Kearifan Tempatan 2013, 6-7 October 2013, Terengganu.

Saadon, R., K. A., \& Saat, I., (2016), Perkembangan Pendidikan Orang Melayu di Malaya Sebelum Kemunculan Western-Type-Education. Jurnal Perspektif. Jil.8 Bil.2. pp.79-86.

Sulaiman, M. (2013), Islam dan Transformasi Sosial Masyarakat Melayu Malaysia : Suatu Kajian Eksploratori. (pp. 24-35), Proceeding of International Conference on Social Science Research (ICSSR 2013 ), 4-5 Jun 2013, Pulau Pinang.

Syakir, A. R. A. (2016), Analisis Mengenai Perkembangan Pendidikan di Indonesia Dari Masa Purba,Hindu- Budhha, Sampai Islam. Academic Exercise of Fakultas Keguruan dan IImu Pendidikan Universitas Lampung. Retrieved from http://www.academia.edu/19041018.

Tamam, B. (2015). Pesantren Nalar dan Tradisi: Geliat Santri Menghadapi ISIS, Terorisme dan Transnasionalisme Islam. Yogyakarta: Pustaka Pelajar.

Tamuri, A. H., \& Ajuhary, M. K. A. ( 2010 ). Amalan Pengajaran Guru Pendidikan Islam Berkesan Berteraskan Konsep Mu'allim. Journal of Islamic and Arabic Education. 2(1). pp. 43-56.

Thukiman, K. (2002). Malaysia: Perspektif, Sejarah Dan Politik, Skudai: Penerbit Universiti Teknologi Malaysia.

Usman, M. (2013). Pesantren, Kiai dan Tarekat dalam Transformasi Sosial, Nizar, H.S. (eds.). Sejarah Sosial \& Dinamika Intelektual Pendidikan Islam di Nusantara. Jakarta: Kencana.

Warren, M. D. (1992), Indigenous Knowledge, Biodiversity Conservation And Development: Keynote address. Proceeding International Conference on Conservation of Biodiversity, Nairobi.

Yahya, M. H. (2001). Islam Di Alam Melayu. Kuala Lumpur: Dewan Bahasa dan Pustaka.

\section{Interview}

Abdullah, L. (2018), (Interview on $13^{\text {th }}$ March 2018), Mudir Pondok Lubuk Tapah, Pasir Mas, Kelantan 